Journal of Comparative International Management

JCIM $\left.\right|_{\text {International Management }} ^{\text {Journal of Comparative }}$

\title{
Audit Committees and Bank Governance: the Case of Tunisian Banks
}

\section{Sana Ben Hassine}

Volume 20, Number 1, 2017

URI: https://id.erudit.org/iderudit/1055450ar

DOI: https://doi.org/10.7202/1055450ar

See table of contents

Publisher(s)

Management Futures

\section{ISSN}

1481-0468 (print)

1718-0864 (digital)

Explore this journal

\section{Cite this article}

Hassine, S. (2017). Audit Committees and Bank Governance: the Case of Tunisian Banks. Journal of Comparative International Management, 20(1). https://doi.org/10.7202/1055450ar

\section{Article abstract}

This paper examines the impact of setting up new audit committees in Tunisian banks on their corporate governance. Specifically studied were the effects of the establishment of audit committees on boards of directors' effectiveness, internal auditor independence, external auditor effort, and internal control and financial reporting quality. The interview and survey methods were used to collect data from board members and the internal and external auditors of eight Tunisian banks shortly after they introduced audit committees on their boards. The main findings show that the establishment of new audit committees influences the breadth of the directors' discussions during board meetings. In some of the banks studied, the new audit committees improve the internal auditors' independence from top management, internal controls and financial reporting quality, and/or result in less effort by external auditors. Some of the interviewed external auditors view the new audit committees as a valuable governance mechanism, especially in cases of disagreement with management. 


\title{
Audit Committees and Bank Governance: the Case of Tunisian Banks
}

\author{
by \\ Sana Ben Hassine \\ HEC Montreal, Quebec, Canada
}

\begin{abstract}
This paper examines the impact of setting up new audit committees in Tunisian banks on their corporate governance. Specifically studied were the effects of the establishment of audit committees on boards of directors' effectiveness, internal auditor independence, external auditor effort, and internal control and financial reporting quality. The interview and survey methods were used to collect data from board members and the internal and external auditors of eight Tunisian banks shortly after they introduced audit committees on their boards. The main findings show that the establishment of new audit committees influences the breadth of the directors' discussions during board meetings. In some of the banks studied, the new audit committees improve the internal auditors' independence from top management, internal controls and financial reporting quality, and/or result in less effort by external auditors. Some of the interviewed external auditors view the new audit committees as a valuable governance mechanism, especially in cases of disagreement with management.
\end{abstract}

\section{Introduction and context}

In recent years, the Tunisian banking industry has undergone major reforms as part of the process of financial liberalization and deregulation of the sector. This phenomenon, which has an international orientation, implies a greater role of the financial market, a decrease in public supervision over banking activities, and greater freedom granted to managers. However, financial liberalization in Tunisia is accompanied by an attempt to reinforce the prudential supervision of banks in order to control their risk management. This is mainly because of the important economic role of banks in financing, the delicate nature of the banking business (the specificity of its assets and liabilities), and the banking crises in similar emerging economies like Malaysia and Indonesia.

In this context, several measures are taken to strengthen internal control mechanisms, in particular the standard for the internal control system of banks (Tunisian accounting standard No. 22). This standard recommends the establishment of audit committees attached to boards of directors in banking institutions. More recently, Central Bank Circular No. 2011-06, Improving Corporate Governance in Financial Institutions, recommends that banks implement audit committees as a signal of good governance practices.

At the international level, the audit committee is strongly recognized as a key element in the corporate governance system (Dellaportas et al., 2012, Ghafran and O'Sullivan, 2013, Agyemang-Mintah and Schadewitz, 2018). In fact, the adoption and use of audit committees is the subject of numerous recommendations in the context of professional reports or regulatory commissions (Treadway, 1987, 
Cadbury, 1992, Blue Ribbon Committee (BRC), 1999, Sarbanes-Oxley (SOX), 2002, etc.). Moreover, a panoply of empirical research investigates different issues related to audit committees (see Carcello et al. (2011) for a review of this literature). However, the research on corporate governance of banks and particularly audit committees remains an underemphasized area, especially in emerging markets (Claessens and Yurtoglu, 2013). Therefore, given the importance of audit committees as a governance mechanism, it is relevant to examine the effects of the establishment of audit committees on Tunisian banks. The purpose of this article is to investigate the potential impact of the establishment of the audit committee on several elements of corporate governance of Tunisian banks. In particular, these aspects relate to the board of directors' effectiveness, relationships with internal and external auditors, financial reporting quality, and internal control quality.

The remainder of the paper is organized as follows. Section 2 outlines the main theories that explain the role of audit committees. Section 3 develops the research propositions. Section 4 describes the research method. Section 5 presents a summary of the results. Section 6 concludes.

\section{Theoretical foundations of audit committees}

\subsection{Agency Theory}

The separation of control/ownership in the modern organization creates conflicting interests between shareholders and managers. According to agency theory, the shareholders act as the principal and delegate the management of their companies to the managers (agents). However, the latter do not often act in the interest of shareholders, hence the need for a control system of managers. This demand for control can be achieved by the use of audits (Wallace, 1980), the appointment of outside directors (Fama and Jensen, 1983), and the setting up of the audit committee. Pincus et al. (1989) argue that audit committees are voluntarily employed in situations of high agency costs to improve the quality of information flow from the agent to the principal. Accordingly, audit committees are seen as a control mechanism designed to reduce agency costs and informational asymmetry (Kalbers and Fogarty, 1998). From this perspective, research on audit committees intends mainly to determine the characteristics of the companies that voluntarily introduce this committee. These studies have examined the association between the audit committee and different variables, for example: agency costs of equity and debt and the quality of external audits (Collier, 1996, Collier and Gregory, 1999, Turley and Zaman, 2002). However, this literature finds mixed results, suggesting that reducing agency costs is not the only incentive for audit committee establishment (Turley and Zaman, 2002).

\subsection{Institutional Theory}

Researchers have examined the implementation of audit committees from an institutional perspective because of the weak explanatory power of agency theory (Kalbers and Fogarty, 1998, Zaman, 2002). Institutional theory, dating back to the 1980s (Dimaggio and Powell, 1983), is based on the fact that organizations adopt new measures in response to external expectations. The institutional perspective suggests that organizations are making changes in their structures and practices in 
the quest for legitimacy and compliance rather than the realization of expected benefits (Kalbers and Fogarty, 1998). In accounting research, for example, institutional theory has been used to examine accounting as a symbol of legitimacy. From this perspective, the audit committee, like accounting, can influence and be influenced by a variety of agents, institutions, and processes (Zaman, 2002). Sources of normative pressure on organizations come from the State, regulatory bodies and the profession. This perspective highlights the role of professional and regulatory bodies in promoting audit committees (Zaman, 2002).

\section{Research Propositions}

The audit committee is a standing committee of the board of directors of a company, often composed of outside directors and responsible for matters related to financial reporting and auditing (Spira, 1999). In particular, the responsibilities of this committee include three areas often mentioned in the literature (Verschoor 1993, Wolnizer 1995, Dellaportas et al., 2012): oversight of the financial statement preparation process, oversight of the internal audit function and the internal control system, and the supervision of the external auditor. In this paper, I propose to examine the effect of the establishment of the audit committee on the effectiveness of the board of directors, internal control and financial reporting quality, internal auditor independence, and the external auditor effort.

\subsection{Audit committees and of board of directors effectiveness}

The role of the board of directors is very important in banks. Macey and O'Hara (2003) note that the nature of the bank makes this organization susceptible to greater moral hazards than industrial firms. In addition, the opacity of the balance sheet of banks and the existence of several regulatory measures, such as deposit insurance, weaken depositors' need to control the risk-taking behavior of managers. They place a great responsibility on the board of directors to control managers and safeguard the social interest.

More freedom is afforded to managers in their decision-making because of the deregulation and liberalization of the banking sector (Kole and Lehn, 1997). It turns out that the duty of control of managers is more important for the board of directors of a bank. The establishment of an additional control mechanism may be of great help to the board in carrying out its responsibilities. In this regard, the audit committee may assist the board of directors in its responsibilities including the preparation of financial statements, the evaluation of internal control, the risk management system and the oversight of internal and external auditors.

Abbott and Parker (2000) argue that forming an audit committee can alleviate the work of outside directors in two ways. On the one hand, outside directors, nonmembers of the audit committee, can discharge their fiduciary duties by relying on the audit committee's opinions on the financial statements. On the other hand, the independence and integrity of controls can be improved, since the external and internal auditors report to a subset of the board made up only of outside directors. Particularly, the board of directors of a bank is responsible not only to the shareholders but also to the regulatory authorities. It has to ensure the quality of disclosed financial information. 
In this study, I focus on the frequency and duration of board meetings, as well as the topics discussed during these meetings. Therefore, I propose that:

Proposition 1: $\quad$ The presence of an audit committee improves the effectiveness of the board of directors.

\subsection{Audit committees and financial reporting quality}

One of the major responsibilities assigned to the audit committee is the oversight of the financial reporting process. The importance of this role is recognized and demonstrated by a large number of proponents, either professionals or regulatory bodies (Treadway, 1987, BRC, 1999, SOX, 2002, Smith report, 2003, etc.).

Studies examining the link between the audit committee and the financial reporting process indicate that the presence of an audit committee contributes significantly to the improvement of financial reporting quality. For this purpose, Dechow et al. (1996) demonstrate that companies subject to SEC sanctions for accounting violations are less likely to have an audit committee. McMullen (1996) demonstrates that the existence of an audit committee is associated with a lower frequency of errors and irregularities in the financial statements. More recently, Piot and Janin (2007) and Baxter and Cotter (2009) show that the presence of an audit committee improves the quality of financial reporting measured by abnormal accounting accruals.

Considering the empirical results for non-financial firms, I expect that establishing an audit committee will have a positive effect on the quality of the financial statements of a bank. Since a bank is required to submit its financial statements to a larger number of users, including regulatory authorities, the presence of the audit committee - the eye overseeing the entire process - would eventually reduce errors, whether intentional or not, in the financial statements. Therefore, I propose that:

Proposition 2: $\quad$ The presence of an audit committee minimizes the risk of errors in the financial statements.

\subsection{Audit committees and internal auditor independence}

The oversight of the internal audit is one of the major responsibilities assigned to the audit committee. In fact, the internal auditor is of great importance to banks. For instance, the presence of an internal auditor in banks is associated with fewer claims for rectification in reports, fewer regulatory violations and a higher probability of detection of employee fraud (Noland and Flesher, 2003).

The internal auditor must be independent and objective to perform effectively (Christopher et al., 2009). However, the CEO is the hierarchical superior of the internal auditor; thus, the latter is in a conflictual situation (BRC, 1999, Christopher et al., 2009). The audit committee can improve the independence of the internal auditor by being an appropriate context for the disclosure of any weaknesses discovered in the company's internal management (Braiotta, 1999). The interaction between the audit committee and the internal auditor is reflected in other actions that 
may also provide a minimum of independence, including: overseeing the appointment and dismissal process of the internal auditor, meetings with the auditor, review of proposals and internal audit results, and private access to the internal auditor (Raghunandan et al, 2001, Christopher et al., 2009). Private meetings allow the latter to express themselves freely and independently of leaders and to pronounce on weaknesses, particularly involving leaders (Braiotta, 1999, Christoper et al., 2009). Therefore, I propose that:

Proposition 3: $\quad$ The presence of an audit committee enhances the independence of the internal audit function.

\subsection{Audit committees and internal control quality}

The BRC Report (1999), the Smith Report (2003), as well as SOX (2002) argue that one of the most important responsibilities of the audit committee is to ensure that an effective system of internal controls is designed and applied in the company. Moreover, the setting up of an audit committee in the banks is recommended as a solution to the difficulties that the board of directors may encounter, in order to ensure the existence and maintenance of an appropriate control system (Basel Committee on Banking Supervision, 2001).

In addition, the existence of an audit committee can be an indicator of the internal control quality (Collier, 1996). In fact, the audit committee is likely to improve the effectiveness of internal controls by overseeing internal and external audit work. In this sense, the results of Abbott et al. (2010) suggest that the focus of the internal audit function on internal control activities increases significantly if the audit committee supervises this function. The empirical results of Krishnan (2005) as well as Pridgen and Wang (2012) indicate that companies that have an audit committee are less likely to have problems of internal control. Therefore, I propose that:

\subsection{Audit committees and external auditor effort}

The audit committee can be involved in the appointment, change and compensation of external auditors, the content and scope of the audit program, as well as the independence of the auditor and the resolution of any disagreement between auditors and managers. Moreover, the rationale behind the recommendations for the establishment of audit committees was often the audit failures revealed in external auditor work (Turley and Zaman, 2002). Better governance of the client permits a higher likelihood of accepting the client, lower risk assessment of the control environment, fewer substantive tests, and more interim testing (Sharma et al., 2008). Cohen et al. (2002) show that $75 \%$ of the surveyed external auditors point out that their discussions with the audit committee or the board have the greatest impact on the audit risk assessment and on the audit planning. These discussions may reveal several risk areas that will affect the planning program in terms of the audit scope. Furthermore, the audit committee is a crucial element of the control environment and its presence signals to the auditors a reduced control risk (Collier, 1996, Stewart and Munro, 2007). As a result, the establishment of an audit committee ensures better control, a reduction of control 
risk and audit risk more generally, thus reducing the external auditor effort (Bradbury et al., 2003). Therefore, I propose that:

Proposition 5: $\quad$ The presence of an audit committee reduces the external auditor's effort.

\section{Research Method}

Wacheux (1996) points out that the case study is applicable when the research question begins with "why" or "how". This research examines how the establishment of the audit committee has an impact on different components of a bank's governance. The case study is therefore an appropriate research strategy. This method is also recommended when the research question is exploratory, which is the case for this study (Yin, 1994).

\subsection{Selection of cases}

Of interest for this research were Tunisian banks that have established audit committees. Questionnaires were sent to internal audit managers (i.e. internal auditors) of Tunisian banks. The results of the survey indicate that twelve Tunisian banks have established an audit committee. They were contacted and eight banks agreed to participate in the study. To maintain confidentiality, the names of these banks are replaced with letters $(\mathrm{A}-\mathrm{H})$.

\subsection{Operationalization of concepts}

Board of directors' effectiveness: This concept is measured by the frequency and duration of board meetings and the topics discussed during these meetings.

Financial reporting quality: The external auditor is responsible for providing an opinion on the regularity and fairness of the financial statements. He is required to communicate to management and to the board the errors and irregularities/misstatements that he noticed when auditing the financial statements, to make the necessary adjustments. The frequency of misstatements detected in the financial statements may be an appropriate measure of the quality of the financial information produced, considering the independence of the external auditor (Archambeault et al., 2008, Cullinan et al., 2008). The presence of the audit committee reduces the likelihood of financial statement anomalies and thus improves the financial reporting quality (McMullen, 1996).

Internal auditor independence: The main factors that determine the independence of the internal auditor are the organizational status of the internal auditor, as well as the degree of managers' involvement in the work of the internal auditor (Chapman, 2001, IIA, 1110).

Internal control quality: The quality of the internal control system is proxied by the frequency of problems in the design or application of internal control procedures (Pridgen and Wang, 2012). This proxy is complemented by the external auditor's 
assessment of the quality of the internal control before and after the establishment of the audit committee. Krishnan (2005) uses a similar measure in his study.

External auditor effort: Some studies use the fees of the external auditor to measure the extent of audit effort (Abbott et al. 2006; Badertscher et al., 2014). However, the audit fees in Tunisia are fixed by a scale. The number of planned audit hours would be a more appropriate measure of audit effort. This measure is used by many studies examining the impact of corporate governance mechanisms on audit effort (e.g., Bradbury et al., 2003; Bedard and Johnstone, 2004; Stewart and Munro, 2007).

\subsection{Data collection and analysis}

For the purpose of this study, three sources of evidence were used: disclosed information, documentation, interviews, and surveys. The utilization of several data sources allows triangulation, which is a corroboration procedure of the data's validity (Patton, 1999).

The documentation included agendas, minutes, audit committee charters, and memos. These documents include information about the main characteristics of the audit committee, as well as the activity and responsibilities of the committee.

Disclosed information included data published by the TSE (Tunis Stock Exchange) and the financial statements and annual reports. The information collected was mainly about the characteristics of the banks studied (total assets, capital structure, nature of activities, external auditors, etc.).

The documentation analysis did not provide a thorough picture of the audit committee's effects on a bank's governance. Accordingly, structured interviews were conducted with the internal audit managers and the external auditor of each bank. To this end, an interview guide was developed based on the research objectives and the literature review. To ensure the rigor and relevance of the questions asked, a pilot test was conducted by submitting the interview guide to two internal audit managers. The interviews lasted from 30 minutes to 1 hour 30 minutes. In addition, questionnaires were sent to the secretaries general of the boards because it was difficult to schedule an interview with them. In total, 16 people were interviewed and questionnaires were completed by 6 persons. Interviews and questionnaires focused on:

- Changes that occurred in the functions studied (internal audit, board of directors, external audit) after the establishment of the audit committee.

- The relationship of the participants interviewed with the audit committee.

- The activity of the audit committee.

To analyze the data collected, the states of the variables studied before and after the implementation of the audit committee in each bank were compared. Moreover, a comparative analysis was performed between the eight banks and insights from the study participants were aggregated. 


\section{Research results}

\subsection{Banks and audit committees studied}

This section describes the banks involved in this study and presents the characteristics of the audit committees they established.

\subsubsection{Bank characteristics}

Eight Tunisian banks agreed to participate in the study. Six banks are in the private sector and two in the public sector. Moreover, six are commercial banks, one a development bank, and one an offshore bank. In addition, six institutions are listed on the Tunis Stock Exchange. Two are large banks (A and $\mathrm{E}^{1}$ ) and four are medium sized banks (B, C, D and $\mathrm{H}^{2}$ ). Except one bank (C), all banks are audited by the big 4 audit firms. Five banks from the private sector and one from the public sector are characterized by concentrated ownership. The ownership is considered to be concentrated if the shareholder holds $50 \%$ or more of the bank's capital. This proxy is used by Kobeissi (2004) in his study on banks in the North African region.

\subsubsection{Audit committee characteristics}

The information about characteristics of the audit committees, as detailed in Table 1, was collected from internal documents (agendas from audit committee meetings, charters, etc.). The audit committee composition varies from one bank to another. The audit committee size is between 3 and 6 members. Based on the criterion of the independence of audit committee members, the banks can be classified into three groups: group 1 includes committees which are entirely formed by executives of the company (A and B), group 2 is where the CEO is a member of the audit committee (C) and finally, group 3 consists of committees formed entirely by non-executive external directors (D, E, F, G, H). The audit committees of group 1 meet twice a year. In groups 2 and 3, the audit committees meet four times a year. These findings suggest that audit committees are probably more active in groups 2 and 3 than in group 1 . 
Table 1. Audit committees characteristics.

\begin{tabular}{|c|c|c|c|}
\hline & Composition & $\begin{array}{l}\text { Frequency } \\
\text { of meetings } \\
\text { (per year) }\end{array}$ & Responsibilities \\
\hline A & $\begin{array}{l}\text { - Supervisory directory } \\
\text { - General inspector } \\
\text { - Internal audit manager } \\
\text { - Computer audit manager }\end{array}$ & Twice & $\begin{array}{l}\text { - Approval of the annual program of internal } \\
\text { audits and inspections. } \\
\text { - Decision-making regarding the } \\
\text { recommendations of audit reports. } \\
\text { - Examination of the main audit conclusions. } \\
\text { - Follow-up of the recommendations of the audit } \\
\text { reports. } \\
\text { - Follow-up of the annual program of audits and } \\
\text { inspections. }\end{array}$ \\
\hline B & $\begin{array}{l}\text { - CEO } \\
\text { - General inspector } \\
\text { - Risk manager }\end{array}$ & Twice & $\begin{array}{l}\text { - Establishment of the annual audit plan. } \\
\text { - Follow up on audit and inspection } \\
\text { recommendations. }\end{array}$ \\
\hline C & $\begin{array}{l}\text { - CEO } \\
\text { - Three affiliated directors }\end{array}$ & Four & $\begin{array}{l}\text { - Review of any document to be provided to the } \\
\text { Tunisian Central Bank, to the public, etc. } \\
\text { - Review of the internal audit report. } \\
\text { - Examination of the evolution of the bank's } \\
\text { situation. } \\
\text { - Examination of forecasts. }\end{array}$ \\
\hline D & $\begin{array}{l}\text { - Tunisian director non-executive } \\
\text { - Two directors representing the } \\
\text { foreign majority shareholder } \\
\text { - Audit committee could rely on } \\
\text { internal or external consultants }\end{array}$ & Four & $\begin{array}{l}\text { - Evaluation of the internal control system. } \\
\text { - Approval of the internal audit plan. } \\
\text { - Review of annual and periodic financial reports. } \\
\text { - Selection of the external auditor. } \\
\text { - Evaluation of the internal auditor's work. } \\
\text { - Verification of compliance with regulations. }\end{array}$ \\
\hline E & $\begin{array}{l}\text { - Vice-president of supervisory } \\
\text { board } \\
\text { - One representative of Ministry } \\
\text { of Finance } \\
\text { - Two representatives of a public } \\
\text { institution }\end{array}$ & Four & $\begin{array}{l}\text { - Review of quarterly financial statements. } \\
\text { - Examination of internal control procedures. }\end{array}$ \\
\hline $\mathbf{F}$ & $\begin{array}{l}\text { - Three Tunisian directors } \\
\text { - Three directors from the country } \\
\text { shareholder }\end{array}$ & Twice & $\begin{array}{l}\text { - Approval of the annual audit plan. } \\
\text { - Discussion of the deficiencies identified by the } \\
\text { internal audit report. } \\
\text { - Discussion of the external auditor's report on } \\
\text { internal control procedures. } \\
\text { - Follow up on auditor recommendations. } \\
\text { - Evaluation of particular accounting choices. } \\
\text { - Selection of the external auditor. }\end{array}$ \\
\hline G & $\begin{array}{l}\text { - Board chairman } \\
\text { - Two external directors } \\
\text { - Internal auditor (as secretary) } \\
\text { - Two managers }\end{array}$ & Four & $\begin{array}{l}\text { - Review of internal audit reports. } \\
\text { - Review of external auditor recommendations. } \\
\text { - Approval of the annual internal audit plan. } \\
\text { - Review of particular accounts (provisions, } \\
\text { guarantees, foreign exchange loss) }\end{array}$ \\
\hline H & $\begin{array}{l}\text { - Board chairman } \\
\text { - Two external directors }\end{array}$ & Four & $\begin{array}{l}\text { - Review of the reports of the control } \\
\text { department. } \\
\text { - Review of financial statements. } \\
\text { - Approval of the annual internal audit plan. }\end{array}$ \\
\hline
\end{tabular}

Regarding the responsibilities of audit committees, as described in Table 2, the supervision of the internal audit function (approval of the annual internal audit plan, review of internal audit results and follow up of the internal auditor recommendations) is a common task of all the audit committees studied. For the other duties, the percentages are variable; for example, $75 \%$ of audit committees are 
responsible for reviewing annual and quarterly financial statements and $62 \%$ of audit committees are responsible for reviewing and following up on the external auditor recommendations. These different responsibilities are formalized in the audit committee charter at one bank (bank D). In the other banks, they are included in the minutes of the board of directors approval of the establishment of the audit committee, by a memo or by a directive of the bank.

Table 2. Responsibilities of audit committees.

\begin{tabular}{ll}
\hline Responsibilities & $\begin{array}{l}\text { Percentage of } \\
\text { audit committees }\end{array}$ \\
\hline Approval of the annual internal audit plan & $100 \%$ \\
\hline Review of the results of the internal audit work & $100 \%$ \\
\hline Follow-up of corrective actions proposed by the internal auditor & $100 \%$ \\
\hline Assessment of effectiveness of the internal control system & $87.5 \%$ \\
\hline Review of quarterly and annual financial statements & $75 \%$ \\
\hline Review and follow-up of external auditor recommendations & $62.5 \%$ \\
\hline Verification of compliance with regulations in effect & $28.5 \%$ \\
\hline
\end{tabular}

\subsection{Interview and survey results}

\subsubsection{Audit committees and effectiveness of the board of directors}

Information about the activity of the board of directors (the number and duration of meetings) was obtained from the questionnaires sent to the secretaries general of the board. As regards the topics discussed during board meetings, the questionnaire provided secretaries with a list of possible subjects to discuss and asked them to rate the time allocation to selected topics (before and after the establishment of the audit committee).

For all banks, the comparison of the frequency and duration of board meetings, before and after the establishment of the audit committee, did not reveal any variations. The majority of boards meet 4 times a year and the duration of these meetings varies between 2 and 4 hours. Moreover, the main topics discussed during board meetings focus on reviewing and approving financial statements, strategic planning, managing key risks and evaluating the institution's current performance. However, in some banks, the time allocated and the nature of these themes changed after the establishment of the audit committee. For instance, the board of directors of bank D devoted more time to strategic issues compared to the review of the financial statements and the assessment of the company's current performance, after the establishment of the audit committee. This committee gives the board a minimum of assurance regarding the reliability of the financial statements prepared. In addition, the establishment of the audit committee enables the boards of banks $F$ and $G$ to address new topics, for example, internal control quality, by consulting the minutes of the audit committee. In sum, for banks D, F and G, the audit committee is a committee that prepares the work for the board of directors in reviewing the financial statements and provides it with a minimum of assurance on the effectiveness of the internal control in place. For banks A and B, being composed of 
non-directors, the audit committee had no direct effect on the effectiveness of the board of directors. ${ }^{3}$

\subsubsection{Audit committees and financial reporting quality}

The information about financial reporting quality was essentially collected from the interview with the external auditor of each bank. The analysis of this data shows that the audit committees of banks A and B are not involved in the review of the financial statements. The audit committees of the other banks pay variable attention to the review of the financial statements. For example, the audit committees of banks $\mathrm{E}$ and $\mathrm{G}$ are interested in examining several balance sheet items that they consider important. Audit committee members of bank E scrutinize client resources, the deposit structure, and changes in net income, while those of bank $\mathrm{G}$ examine guarantees, provisions, and foreign exchange losses. Other committees (banks $\mathrm{C}, \mathrm{D}, \mathrm{F}$ and $\mathrm{H}$ ) are responsible for reviewing the recommendations of the external auditor related to the financial statements.

However, this particular interest in the financial statements has no significant effect on the quality of the financial information produced. The second proposition about the positive effect of the presence of audit committees on financial reporting quality is not confirmed. The frequency of misstatements/errors discovered in financial statements by the external auditor did not change significantly after the establishment of the audit committee, except in bank E. This result can be explained by the lack of financial literacy of the audit committee members and the inactivity of the audit committee in some cases. In fact, as the GAO survey (1991) points out, the accounting expertise of members is a key factor in obtaining more reliable financial statements for banks.

\subsubsection{Audit committees and internal auditor independence}

Information about the elements that determine internal auditor independence was gathered from the interview with the internal audit manager of each bank. These elements include the appointment of the internal audit manager, the hierarchical superior of the internal audit manager, the approval of the charter and the annual internal audit plan, and the channels of communication between the audit committee and the internal audit manager.

Internal audit is a division under the supervision of top management in 5 out of 8 banks. Moreover, the appointment, dismissal and remuneration of the internal audit manager remains exclusively within the remit of top management even after the establishment of the audit committee. Only the audit committee of bank D participates in such decisions. As regards the functional relationship, the internal audit manager reports his results to top management and the audit committee in three banks (D, F and G). However, it continues to report only to top management even in the presence of the audit committee in the other banks. In addition, the approval of the annual internal audit program is attributed to the audit committee in all banks while the approval of the internal audit charter is assigned to top management (A and $\mathrm{C})$ and the audit committee ( $\mathrm{F}$ and $\mathrm{G}) .{ }^{4}$ Finally, the internal audit manager participates in audit committees meetings in 4 cases (D, E, F and G). He has private meetings with audit committee members ${ }^{5}$ in only two banks (D and G). These findings suggest that top management still has control on the internal audit function, 
even after the establishment of the audit committee, both hierarchically and functionally in 6 out of 8 cases. According to the internal audit managers of these banks, this result can be explained by the resistance of top managers to the direct relationship between the internal auditor and the audit committee.

However, in banks D and G, the independence of the internal audit manager is improved because the internal audit manager can communicate directly with the audit committee which participates in the appointment and change of the internal audit manager. Moreover, the private meetings organized with audit committee members allow the internal audit manager to express his opinions freely, away from the pressures that could be exerted by managers. This is not the case for other banks, where internal audit reports go through top management before being reviewed by the audit committee.

\section{Table 3. Independence of internal audit manager.}

\begin{tabular}{|c|c|c|}
\hline & $\begin{array}{l}\text { Before audit committee } \\
\text { establishment (number } \\
\text { of banks) }\end{array}$ & $\begin{array}{l}\text { After audit committee } \\
\text { establishment }\end{array}$ \\
\hline \multicolumn{3}{|c|}{ Hierarchical superior of internal audit manager } \\
\hline - Top management & 7 & 5 \\
\hline - General inspection & $1(\mathrm{~A})$ & $2(A, B)$ \\
\hline - Control department & & $1(\mathrm{H})$ \\
\hline \multicolumn{3}{|l|}{$\begin{array}{l}\text { Appointment, dismissal and remuneration of } \\
\text { internal audit manager }\end{array}$} \\
\hline - Top management & 7 & 7 \\
\hline - Top management and board of directors & $1(D)$ & \\
\hline - Top management and audit committee & & $1(D)$ \\
\hline \multicolumn{3}{|l|}{ Internal audit manager reports directly to } \\
\hline - Top management & 7 & 5 \\
\hline - Top management and board of directors & 1 (D) & \\
\hline - Top management and audit committee & & 2 ( $D$ et $F)$ \\
\hline - Audit committee & & $1(G)$ \\
\hline \multicolumn{3}{|l|}{ Approval of internal audit charter } \\
\hline - Top management & 4 & 2 (A et $C$ ) \\
\hline - Audit committee & & 2 (F et G) \\
\hline
\end{tabular}

Approval of annual planning of internal audit

- Top management

- Audit committee

Communication between internal audit manager and audit committee

- Attending audit committee meetings

- Yes

- No

- Private meetings

- Yes

- No

NA: not applicable 


\subsubsection{Audit committees and internal control quality}

In the majority of the banks studied, the audit committee evaluates the internal control system by consulting the internal control report, reviewing the internal audit reports, as well as reviewing the recommendations of the external auditor on internal controls.

The different elements of the impact of the audit committee on internal control quality were gathered from the interviews with the internal audit manager and with the external auditor of each bank. The results indicate that the presence of the audit committee is associated with a greater detection of internal control weaknesses in three cases (banks A, D and G). This result can be explained by the fact that the establishment of the audit committee allowed the internal audit manager to be more efficient in his work. In fact, according to the internal audit managers of these banks, the establishment of the audit committee is accompanied by closer monitoring of the internal audit activity and greater attention to its recommendations from top management. The auditor is prompted to conduct more effective audits. In addition, the internal and external auditors of 4 banks (A, B, D and G) consider the presence of the audit committee to have allowed a more regular and rigorous follow-up of the audit recommendations relating to weaknesses in internal control.

In other banks (B, C, E, G and H), the presence of the audit committee has no effect on the number of the problems detected in internal control procedures. The internal audit managers of these banks consider that the limited effect of the audit committee on internal control quality is caused by the lack of power given to internal audit managers to implement the recommendations intended to strengthen this internal control system. In addition, the internal control processes in place suffer from several shortcomings, including the absence of a written procedures manual. As a result, the control culture at these banks remains relatively weak.

\subsubsection{Audit committees and external auditor effort}

Three main findings come out of the analysis of the interviews with the external auditor of each bank. The first result is consistent with proposition 5, i.e., in the presence of the audit committee, the external auditor reduces the scope of its planned audit effort. In fact, the planned audit effort (in hours) decreased for three banks (E, F and G) after the establishment of the audit committee. According to the external auditors of these banks, this result can be explained by the fact that they rely on audit committees to identify potential risk areas.

Second, the auditors of banks D, F and $\mathrm{H}$ consider the audit committee as a supporter in case of potential disagreements with management. In such situations, the audit committee takes an impartial position and tries to solve the problem, or in other cases, it supports the opinion of the external auditor. The audit committee is considered an indispensable governance mechanism, facilitating the implementation of the auditor's recommendations.

Third, the presence of audit committees in Banks A, B and C did not have any effect on the conduct of the audit engagement. Planned audit hours did not change after the establishment of the committee. The external auditors considered these 
committees ineffective as a control mechanism. In addition, communication between the audit committee and the auditor was absent, unlike the other banks where a minimum of communication was established, whether formally (banks D, F, G and $\mathrm{H}$ ) or informally (bank E). The auditors of banks D, F, G and H participate occasionally or at all audit committee meetings, to present the audit results and communicate the auditor's recommendations on the financial statements.

In sum, audit committees are more effective in some banks than in other banks. Indeed, the simple existence of the audit committee does not guarantee its effectiveness (Menon and Williams, 1994; Dellaportas et al., 2012). Its impact can be moderated by several factors. The next section identifies the elements that explain the lack of effectiveness of the audit committee in fulfilling its role in some banks.

\subsubsection{Additional results and discussion}

The results, described above, indicate that in some of the banks studied, the audit committee has limited effects on internal auditor independence, and financial reporting and internal control quality. Possible explanations of this finding can be identified based on the collected opinions of the internal and external auditors of these banks.

The interviewed participants noticed that the newly established audit committees in some of these banks lack independence and competence. For instance, audit committee members of banks A and B are employees of the bank, which can explain the committee's lack of independence and ineffectiveness. In bank $\mathrm{C}$, top managers are members of the audit committee. This puts pressure on the external auditor who is expected to provide an unbiased opinion on the quality of the financial statements and the internal control system. The external auditor of this bank considers the audit committee to be ineffective and that its establishment has no beneficial effects on the internal control system and the reliability of the financial statements. In other cases (banks $\mathrm{G}$ and $\mathrm{H}$, for example), the committee members do not have the required skills, especially accounting competencies, to fulfill their role. Moreover, the study participants recognized other factors that may have triggered the lack of effectiveness of audit committees such as: the little power attributed to the audit committee, the small number of committee meetings, the unavailability of committee members, the lack of information provided to the committee members, and the weak internal control environment.

Taken together, these results raise questions about the real desire of these banks to improve their governance systems. They may have introduced audit committees just to respond to increasing institutional pressures from either regulatory authorities or good governance practices dictated by globalization. 
Table 4. External auditor and audit committees.

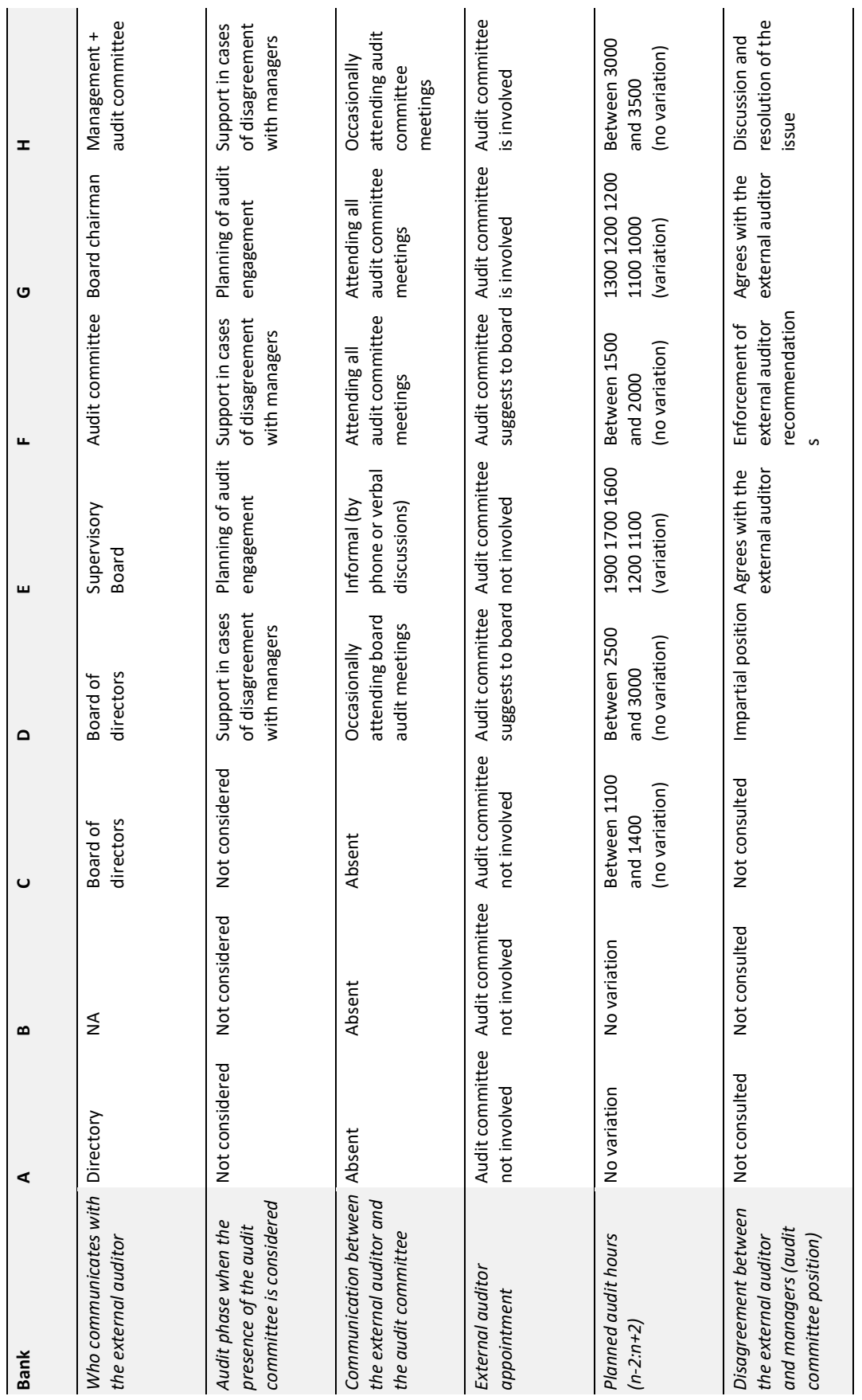

$n$ : year of audit committee establishment 


\section{Conclusion}

The objective of this research is to investigate the impact of the implementation of new audit committees in eight Tunisian banks on their governance. In particular, the effects of new audit committees on boards of directors' effectiveness, internal auditor independence, external auditor effort, and internal control and financial reporting quality were examined.

The main results indicate that the establishment of new audit committees influences the breadth of the directors' discussions during board meetings. In some of the banks studied, the new audit committees improve the internal auditor's independence from top management, internal control and financial reporting quality, and/or results in less effort by the external auditor. Some of the interviewed external auditors view the new audit committees as a valuable governance mechanism, especially in cases of disagreement with management. Overall, the audit committees of banks D, E, F, G and $\mathrm{H}$ (group 3) are reasonably effective in fulfilling their monitoring role of the internal audit function, the financial reporting process, and the internal control system. In the remaining banks A, B and C (groups 1 and 2), audit committees are ineffective. The lack of effectiveness of these committees is essentially triggered by the lack of independence and competence of its members.

The study has limitations. First, the case study methodology is open to subjectivity from the researcher when interpreting the perceptions collected from the different participants. Second, the audit committee members were not interviewed, which limits the study's insights about audit committees' meetings.

Potential avenues for future research include investigating the reasons behind the absence of audit committees in other Tunisian banks (for example, the hypothesis of management entrenchment). It would also be interesting to study the effectiveness of audit committees in non-financial industries. In addition, the research method and results of this study could be insightful to researchers interested in examining the effectiveness of audit committees in other emerging countries. Finally, it would be worthwhile to investigate the substitutability and/or complementarity between the audit committee and other governance mechanisms in the banking sector.

\section{Acknowledgements}

I would like to thank S.M. Chtourou, W. Khoufi and R. Shabou for their comments that greatly improved the quality of this paper.

\section{Endnotes}

${ }^{1}$ The size of the bank (measured by the total assets) is between 2000 (million

Tunisian dinars) and 4000 MTD.

${ }^{2}$ Size is between 1000 and 2000 MDT. 
${ }^{3}$ For banks $\mathrm{C}$ and $\mathrm{E}$, the audit committee did not have an impact on any aspect of the board of directors' effectiveness (frequency/duration of meetings and topics discussed).

${ }^{4} 4$ banks don't have an internal audit charter.

${ }^{5}$ Without the presence of top managers.

\section{References Heading}

Abbott, L. J., S. Parker, \& G.F., Peters. 2010. Serving two masters: association between audit committee internal audit oversight and internal audit activities. Accounting Horizons, 24(1): 1-24.

Abbott, L. J., Parker, S., \& G. F., Peters. 2006. Earnings management, litigation risk, and asymmetric audit fee responses. Auditing: A journal of Practice \& theory, 25(1): 85-98.

Abbott, L. J. \& S. Parker. 2000. The effects of audit committee activity and independence on corporate fraud. Managerial Finance, 26(11): 55-67.

Act, S. O. 2002. Sarbanes-Oxley Act (SOX). Washington DC.

Archambeault, D. S., F. T., DeZoort \& D. R., Hermanson. 2008. Audit committee incentive compensation and accounting restatements. Contemporary Accounting Research, 25(4): 965-992.

Agyemang-Mintah, P., \& H., Schadewitz. 2018. Audit committee adoption and firm value: evidence from UK financial institutions. International Journal of Accounting \& Information Management, 26(1): 205-226.

Badertscher, B., B. Jorgensen, S. Katz, \& W. Kinney. 2014. Public equity and audit pricing in the United States. Journal of Accounting Research, 52(2): 303-339.

Basel Committee on Banking Supervision. 2001. Internal Audit in Banks and the Supervisor's Relationship with Auditors. Bank of International Settlements.

Baxter, P., \& J., Cotter. 2009. Audit committees and earnings quality. Accounting \& Finance, 49(2): 267-290.

Bedard, J. C., \& K. M., Johnstone. 2004. Earning manipulation risk, corporate governance risk and auditors' planning and pricing decision. The Accounting Review, 79(April): 277-304.

Blue Ribbon Committee (BRC) on improving the effectiveness of corporate audit committees. 1999. Report and Recommendations of the Blue Ribbon Committee on Improving the Effectiveness of Corporate Audit Committees, New York: New York Stock Exchange and NASDAQ.

Bradbury, M., N. B., Redmayne \& S. F., Cahan. 2003. An examination of the effect of political costs and corporate governance on audit effort: evidence from the New Zealand public sector using audit hour data. 2003 AFAANZ Annual Conference Brisbane, Queensland, 6-8 July.

Braiotta, L. 1999. The Audit Committee Handbook, $2^{\text {nd }}$ Edition. New York: John Wiley \& Sons Inc. 
Cadbury Committee. 1992. Report of the Committee on the Financial Aspects of Corporate Governance. London: Professional Publishing Ltd.

Carcello, J. V., D. R., Hermanson, , \& Z., Ye. 2011. Corporate governance research in accounting and auditing: Insights, practice implications, and future research directions. Auditing: A Journal of Practice \& Theory, 30(3): 1-31.

Chapman, C. 2001. Raising the bar. Internal Auditor, 58(2): 55-59.

Christopher, J., G., Sarens, \& P., Leung. 2009. A critical analysis of the independence of the internal audit function: evidence from Australia. Accounting, Auditing \& Accountability Journal, 22(2): 200-220.

Claessens, S., \& B. B., Yurtoglu. 2013. Corporate governance in emerging markets: A survey. Emerging Markets Review, 15: 1-33.

Cohen, J., Krishnamoorthy, G., \& A. M., Wright. 2002. Corporate governance and the audit process. Contemporary accounting research, 19(4): 573-594.

Collier, P., \& A., Gregory. 1999. Audit committee activity and agency costs. Journal of Accounting and Public Policy, 18(4-5): 311-332.

Collier P.A. 1996. The rise of the audit committee in UK quoted companies: a curious phenomenon. Accounting, Business and Financial History, 6 (2): 121-140.

Cullinan, C. P., Du, H., \& Wright, G. B. 2008. Is there an association between director option compensation and the likelihood of misstatement? Advances in Accounting, 24(1): 16-23.

Dechow, P. M., R. G. Sloan \& A- P., Sweeney. 1996. Causes and consequences of earnings manipulation: An analysis of firms subject to enforcement actions by the SEC. Contemporary accounting Research, 13(spring): 1-36.

Dellaportas, S., Leung, P., \& B. J., Cooper. 2012. Observations on audit committee characteristics. Managerial Auditing Journal, 27(4).

DiMaggio P., \& W., Powell. 1983.The iron cage revisited: institutional isomorphism and collective rationality in organisational fields. American Sociological Review, 48(2): 147-60.

Fama, E., \& M., Jensen. 1983. Separation of ownership and control. Journal of Law and Economic 26(2): 301-325.

General Accounting Office (GAO). 1991. Audit Committees: Legislation Needed to Strengthen Bank Oversight, Washington, D.C.: Report to Congressional Committees.

Ghafran, C., \& N., O’Sullivan. 2013. The governance role of audit committees: reviewing a decade of evidence. International Journal of Management Reviews, 15(4): 381-407.

Internal Auditor Association (IIA). (2001). Practice Advisory 1110-1: Organizational Independence, January 5, 2001.

Kalbers, L., \& J.T., Fogarty. 1998. Organization and economic explanations of audit committee oversight. Journal of Managerial Issues, 10 (2): 129-150. 
Kobeissi, N. 2004. Ownership structure and bank performance: Evidence from the Middle East and North Africa. Paper presented at the $11^{\text {th }}$ conference of ERF (Economic Research Forum), Liban, December 2004.

Kole, S.R., K.M. Lehn. 1997. Deregulation, the evolution of corporate governance structure, and survival. American Economic Review, 87: 421-425.

Krishnan J. 2005. Audit committee quality and internal control: An empirical analysis. The Accounting Review, 80 (April): 649-676.

Macey, J.R., M., O’Hara. 2003. The corporate governance of banks. FRBNY Economic Policy Review, 9: 91-107.

McMullen, D.A. 1996. Audit committee performance: an investigation of the Consequences associated with audit committees. Auditing: A Journal of Practice \& Theory, 15(spring): 87-103.

Menon, K., \& J.D., Williams. 1994. The use of audit committees for monitoring. Journal of Accounting \& Public Policy, 13: 121-139.

Noland, T. G., \& D. L., Flesher. 2003. An assessment of the internal auditor's impact in small banks. Internal Auditing, 18(1): 40-44.

Patton, M. Q. (1999). Enhancing the quality and credibility of qualitative analysis. Health services research, 34(5 Pt 2), 1189.

Piot, C., \& R., Janin. 2007. External auditors, audit committees and earnings management in France. European Accounting Review, 16(2): 429-454.

Pincus, K., M. Rusbarsky \& J., Wong. 1989. Voluntary formation of corporate audit committees among NASDAQ firms. Journal of Accounting \& Public Policy, 8: 239-265.

Pridgen, A., \& K. J., Wang. 2012. Audit committees and internal control quality: Evidence from nonprofit hospitals subject to the Single Audit Act. International Journal of Auditing, 16(2): 165-183.

Raghunandan, K., D. V., Rama, \& W. J., Read. 2001. Audit committee composition, "gray directors," and interaction with internal auditing. Accounting Horizons, 15(2): 105-118.

Sharma, D. S., E. F., Boo, \& V. D., Sharma. 2008. The impact of non-mandatory corporate governance on auditors' client acceptance, risk and planning judgments. Accounting and Business Research. 38(2): 105-120.

Smith Committee. 2003. Audit Committee-Combined Code Guidance, Financial Reporting Council, London, http://www.frc.org.uk/publications.

Spira, L. F. 1999. Ceremonies of governance: Perspectives on the role of the audit committee. Journal of Management and Governance, 3: 231-260.

Stewart, J., \& L., Munro. 2007. The impact of audit committee existence and audit committee meeting frequency on the external audit: Perceptions of Australian auditors. International Journal of Auditing, 11(1): 51-69.

Tunisian Accounting Standards Committee. 1999. Standard 22: Organization and system of internal control of banking institutions, Official Journal of the Republic of Tunisia, December 31. 
Treadway Commission. 1987. Report of the national commission on fraudulent financial reporting. Washington, DC: National Commission on Fraudulent Financial Reporting.

Turley, S., \& M., Zaman. 2002. Global presence yet no difference: Corporate governance effects of audit committees. Paper presented to the Critical Perspectives on Accounting Conference, Baruch College, City University of New York, April.

Verschoor, C.C. 1993. Benchmarking the audit committee. Journal of Accountancy, 176: 59-64.

Wacheux, F. 1996. Qualitative Methods and Research in Management, Gestion, 290p, Ed Econmica, France.

Wallace, W. 1980. The Economic Role of the Audit in Free and Regulated Markets, Sarasota, FL: American Accounting Association.

Wolnizer, P.W. 1995. Are audit committees red herrings? Abacus, 31 (March): 45-66.

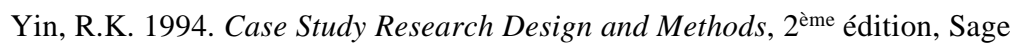
Publication.

Zaman, M. 2002. Globalisation of corporate governance: An alternative framework for conceptualising innovation and effects. Paper presented to the Critical Perspectives on Accounting Conference, City University of New York, April. 